\title{
Can the Health Club be Used Effectively to Promote Healthy Lifestyles? A Comparison of Health Club Members and Community Controls in Khayelitsha, Cape Town
}

\author{
Isaacs Roshan and Puoane Thandi \\ School of Public Health, University of the Western Cape, P/Bag X17, \\ Bellville.7535 South Africa \\ E-mail: *<roshan.isaacs@gmail.com>,**<tpuoane@uwc.ac.za>
}

KEYWORDS Urban Township. South Africa. Health Club. Healthy Lifestyles. Physical Activity. Eating Practices

\begin{abstract}
In response to the increasing need to reduce the burden associated with chronic non-communicable diseases, a health club was developed in 2002 to promote healthy lifestyles in Khayelitsha, an urban township in Cape Town. The current study assessed the effectiveness of the health club in promoting healthy living by comparing club members practices of physical activity and eating habits with community controls. It also identified perceived barriers and enhancing factors in both groups. Data was collected through interviews using structured questionnaires. Fewer health club members $(8 \%)$ than non-members $(23 \%)$ walked for more than 30 minutes daily $(\mathrm{p}=0.025)$. Members were in general more active than non-members. Members $(28 \%)$ spent more time than non- members $(8 \%)$ engaged in light intensity daily activities for more than 2 hours $(\mathrm{p}=0.029)$. Fifty- eight percent of members and $20 \%$ of non-members spent more than 3 hours daily engaged in moderate physical activity $(\mathrm{p}=0.002)$. Members mostly made healthier food choices and cooking methods than non- members. Sixty- nine percent of club members always trimmed fat from red meat whereas 79 percent of nonmembers never trimmed fat $(\mathrm{p}=0.000)$. More non-members $(96 \%)$ than members $(39 \%)$ ate soft rather than hard margarine $(\mathrm{p}=0.000)$. Thirty- six percent of members and 5 percent of non-members consumed less than 2 teaspoons of sugar in their tea/coffee $(p=0.000)$. This study indicates that the health club had a positive effect in influencing healthy living among its members. However, socio-economic and environmental factors pose significant barriers in the adoption of healthy behaviours.
\end{abstract}

\section{BACKGROUND}

The leading chronic non-communicable diseases induce cardiovascular disease, then cancer, chronic lung diseases and diabetes mellitus (Yach et al. 2004). It is predicted that chronic non-communicable diseases would have accounted for $80 \%$ of the global burden of disease by 2020 , causing seven out of every ten deaths in developing countries compared with less than half today (WHO 1997). Despite this increasing trend and its disproportionate effect on poor populations, the control of chronic non-communicable diseases is generally not given high priority in poor populations (Puoane et al. 2006). Physical inactivity and unhealthy diets contribute substantially to this global burden of disease, death and disability (WHO 2004). Since 1994,

Corresponding author:

Thandi Puoane,

Private Bag X17,

Bellville. 7535. South Africa.

Telephone: 27219592809

Fax: 2719592872.

E-mail: tpuoane@uwc.ac.za
South Africa has seen a large movement of the black population from rural to urban sites. This is in search of better work and living conditions in the cities (Peberdy 2009). Research shows that as people migrated towards the cities staple traditional foods are often replaced by unhealthy foods which are easily accessible, many of which are high in fat and sugar and have low nutrient value (Steyn 2006). Bourne et al. (2000) have shown that among urban blacks, fat intake has increased from 16.4 percent to 26.2 percent of total energy (a relative increase of 59.7\%), while carbohydrate intake has decreased from 69.3 percent to 61.7 percent of total energy (a relative decrease of $10.9 \%$ ) in the past 50 years. Little data is available on the prevalence of physically active lifestyles of older adults in Sub-Saharan Africa. In a study to investigate the prevalence of Type 2 diabetes mellitus and its risk factors in a working class peri-urban community of mixed ancestry (coloured men and women) in South Africa, it was found that approximately half of the subjects did not participate in the recommended 150 minutes or more per week recommended to achieve health benefits (Levitt et al. 
1999). While physical activity appears to be protective of chronic non-communicable diseases, review of data on the prevalence of physical activity in South Africa suggest that individuals over the age of 55 years have the lowest levels of selfreported moderate and vigorous physical activity and that these South African seniors spent 65\% less energy than North Americans of the same age (Lambert and Kolbe-Alexander 2006). Physical activity appears to be protective of chronic diseases, acutely lowering serum triglyceride concentrations, improving tissue sensitivity to insulin, increasing fibrinolytic activity and high density lipoprotein (HDL) cholesterol, and decreasing clotting activity and blood pressure (Lambert et al. 2001b).

The literature also shows that diets high in fruit and vegetables and low in meat are protective against the development of chronic diseases (Vorster et al. 2001).

The development of interventions to reduce the burden associated with chronic non-communicable diseases has become a necessity. Hence, a health club focusing on diet and physical activity was initiated in Khayelitsha, an urban township of Cape Town, by the School of Public Health of the University of the Western Cape. Community health workers were trained and they in turn recruited members from the areas where they lived and worked to join the health club. The club which is the primary focus of this paper, functions more as a group of individuals coming together to learn about healthy lifestyles and provide support to each other irrespective of whether they have had dedicated accommodation for the group or not. Members come together at least once a week for education sessions on healthy eating, food hygiene and the importance of engaging in physical activity. They also participate in physical exercises and cook healthy meals together on a weekly basis. These meals are served with and recipes are shared among participants.

Education around physical activity and nutrition followed the 2001 South African Food Based Dietary Guidelines document (Vorster et al. 2001). Weight, height and blood pressure of members were taken at the time of joining and were monitored monthly thereafter. No information was collected on baseline physical activity and dietary habits of the club members. There is a lack of relevant information about the benefits of health clubs particularly in poorer communi- ties. This study assessed the effectiveness of the health club in increasing physical activity and improving eating habits among the members

\section{METHODOLOGY}

\section{Study Design, Setting and Subjects}

This was a non- experimental post-intervention study in which the intervention (health club members) and the control groups (non -club members) were compared. As baseline data on physical activity and dietary habits of club members was not collected, it was assumed that at the beginning of the intervention both populations had similar practices in terms of physical activity and eating habits.

The study was undertaken in Khayelitsha, a predominantly black-urban township located about 40km south- east from the centre of Cape Town. It is spread over $30 \mathrm{~km}^{2}$ and is home to approximately 459000 people (Wikipedia: Khayelitsha). The township is made up of a combination of formal low-cost housing and informal housing. Fifty- one percent of the economically active population is unemployed. While it is populated mainly by those who have left rural Eastern Cape to seek jobs in Cape Town, the residents of Khayelitsha remain in a very large economically, spatially and racially marginalized centre from the city (Du Toit and Neves 2007).

Due to the small number of health club members, all 26 regular members participated in the study. The control group was from the same community and it was made up of approximately twice the number (60) of the members to increase the statistical power of the sample and to be able to detect a difference between the two groups based on outcome measures. Five male health club members were excluded as it was felt that their practices of physical activity and dietary habits could differ greatly from that of the women.

Ethical approval was granted by the ethics committee of University of the Western Cape. Data was collected during November 2006 to February 2007.

Data was collected through face to face interviews by trained interviewers using a structured questionnaire. Data collected included:

- Frequency and/or duration of various physical exercises and activities. 
- Factors which inhibited and enhanced increased physical activity.

- Types, quantities and frequencies of consumption, as well as preparation of various foods such as vegetables and sugary foods.

- Factors which inhibited and enhanced improved dietary habits.

Light physical activity included 'daily walking' and 'daily meal preparation and cleaning up after meals'. Moderate physical activity included 'weekly moderate structured exercise' and 'moderate daily routine dusting and cleaning'. Vigorous household activity involves work such as 'washing windows, chopping wood, scrubbing floors, fetching water and sweeping the yard'.

Data was analysed using the Statistical Package for Social Sciences (SPSS) programme. Frequencies and percentages were computed. Crosstabulations and chi-squared tests were used to test for association between variables. Because the independent variables consisted of more than one category, a single p- value of 0.05 was represented to indicate whether the two groups (health club members vs. community non- members) differed significantly from each other.

\section{FINDINGS}

Demographic characteristics of particpants are displayed in $\mathrm{T}$ able 1.

\subsection{Participation in Physical Activity}

3.1.1 Participation in Light Physical Activity: Participants were asked how many minutes they walked daily.

As illustrated in Figure 1, a large percentage (92\%) of members and $77 \%$ of non- members walked for less than 30 minutes daily and a small percentage, $8 \%$ and $23 \%$ of members and nonmembers respectively, walked for more than 30 minutes. This difference is statistically significant $(\mathrm{p}=0.025)$.

Members also spent significantly more time in meal preparation and cleaning up after meals than non- members $(\mathrm{p}=0.029)$ (data not shown).

\subsubsection{Participation in Moderate Physical} Activity: As illustrated in Figure 2, although members and non-members spent similar lengths of time engaged in moderate exercise, more members than non- members spent in excess of 2 hours doing this.

Fifty- eight percent of members and $20 \%$ of non-members participate in household tasks of
Table 1: Demographic characteristics of participants $(\mathbf{n}=\mathbf{8 6})$

\begin{tabular}{|c|c|c|c|c|}
\hline \multirow[t]{2}{*}{ Variables } & \multicolumn{2}{|c|}{$\begin{array}{l}\text { Members } \\
(n=26)\end{array}$} & \multicolumn{2}{|c|}{$\begin{array}{l}\text { Non-member } \\
(n=60)\end{array}$} \\
\hline & $\begin{array}{l}\text { Fre- } \\
\text { quency }\end{array}$ & $\%$ & $\begin{array}{l}\text { Fre- } \\
\text { quency }\end{array}$ & $\%$ \\
\hline \multicolumn{5}{|l|}{ Age } \\
\hline $\begin{array}{l}50 \text { years } \\
\text { and younger }\end{array}$ & 3 & 12 & 12 & 20 \\
\hline $51-60$ years & 9 & 35 & 24 & 41 \\
\hline More than 60 & 14 & 54 & 23 & 39 \\
\hline Missing responses & 0 & 0 & 1 & \\
\hline \multicolumn{5}{|l|}{ Employment Status } \\
\hline Unemployed & 23 & 92 & 46 & 78 \\
\hline Part-time & 1 & 4 & 7 & 12 \\
\hline Full time & 0 & 0 & 3 & \\
\hline Self-employed & 1 & 4 & 3 & \\
\hline Missing responses & 1 & 0 & 1 & \\
\hline \multicolumn{5}{|l|}{ Education Level } \\
\hline No schooling & 7 & 29 & 20 & 35 \\
\hline Primary school & 13 & 54 & 22 & 39 \\
\hline High school & 4 & 17 & 15 & 26 \\
\hline Missing responses & 2 & 0 & 3 & 0 \\
\hline \multirow{2}{*}{\multicolumn{5}{|c|}{ Living in Household }} \\
\hline & & & & \\
\hline One & 6 & 23 & 6 & 11 \\
\hline Two & 11 & 42 & 18 & 32 \\
\hline Three or more & 9 & 35 & 32 & 57 \\
\hline Missing responses & 0 & 0 & 4 & 0 \\
\hline
\end{tabular}

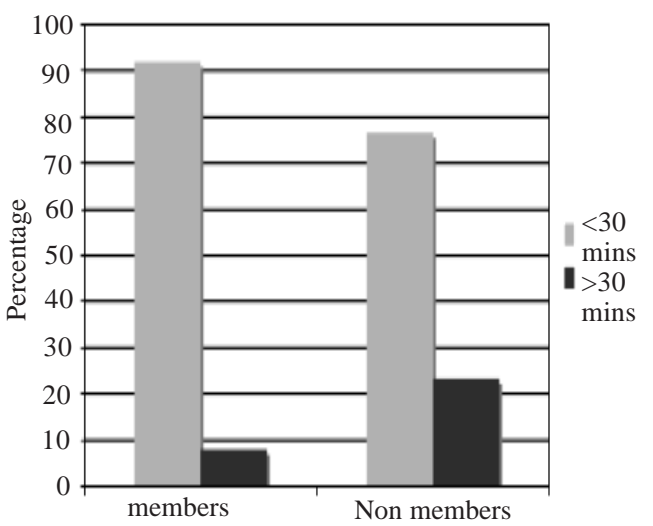

Fig. 1. Time spent walking (in minutes) by members and non-members

moderate intensity for more than 3 hours daily. The difference was statistically significant $(\mathrm{p}=$ $0.002)$.

3.1.3 Participation in Vigorous Activities: Participants were asked how many times per month they engaged in vigorous activities such as washing windows, chopping wood, scrubbing floors, fetching water and sweeping the yard. Responses are shown in Figure 3.

As illustrated in Figure 3, although members 


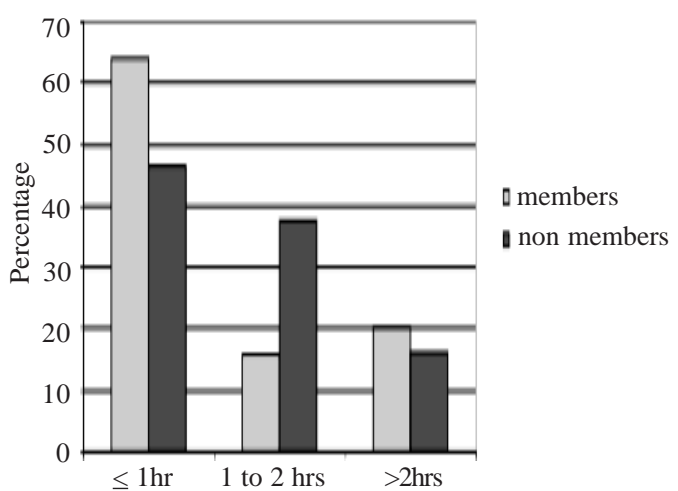

Fig. 2. Participation in moderate exercise per week (in hours) of members and non- members

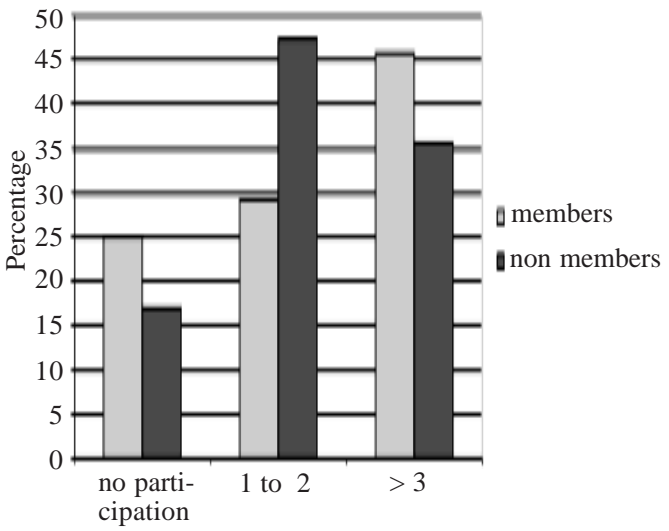

Fig. 3. Number of times engaged in vigorous cleaning per month by members and non- members

and non-members spent similar lengths of time doing these activities of vigorous intensity, members did these more often on a monthly basis than non-members.

3.1.4 Time Spent Watching Television: Television watching is used as a proxy of a sedentary lifestyle. The $92 \%$ and $95 \%$ of members and nonmembers respectively who watch television were asked how many hours they spent watching television daily (See Table 2).

Although not statistically significant $(\mathrm{p}=$ 0.379 ), members spent less time watching television than non-members.

3.1.5 Perceived Barriers and Enhancing Factors for Improved Physical Activity: Participants were given a list of perceived barriers and enhancers for improved physical activity. They were asked to choose those factors that applied to them and to add any that were not on the list (see Tables 3 and 4).
Table 2: Hours spent watching television daily by participants

\begin{tabular}{|c|c|c|c|c|}
\hline \multirow{2}{*}{$\begin{array}{l}\text { Daily no. of } \\
\text { hours spent } \\
\text { watching } \\
\text { television }\end{array}$} & \multicolumn{2}{|c|}{ Members } & \multicolumn{2}{|c|}{ Non-members } \\
\hline & $\begin{array}{r}\text { Frequ } \\
\text { ency }\end{array}$ & $\%$ & $\begin{array}{l}\text { Frequ } \\
\text { ency }\end{array}$ & $\%$ \\
\hline $\begin{array}{c}\text { Less than } \\
1 \text { hour }\end{array}$ & 7 & 28 & 11 & 19 \\
\hline $\begin{array}{l}\text { Between } \\
1-2 \text { hours }\end{array}$ & 14 & 56 & 30 & 52 \\
\hline $\begin{array}{l}\text { More than } \\
2 \text { hours }\end{array}$ & 4 & 16 & 17 & 29 \\
\hline $\begin{array}{l}\text { Missing } \\
\text { responses }\end{array}$ & 1 & 0 & 2 & 0 \\
\hline
\end{tabular}

Perceived barriers to improved physical activity by members were health problems, family commitments, personal problems, feeling too tired and pain associated with exercise. Those perceived by non- members were: laziness, a lack of exercise facilities, feeling unsafe, feeling too tired and pain associated with exercise.

Table 3: Members and non- members perceived barriers for physical activity

\begin{tabular}{lll}
\hline Perceived barriers & $\begin{array}{ll}\text { Club mem- } \\
\text { bers } \%\end{array}$ & $\begin{array}{l}\text { Comm- } \\
\text { unity mem } \\
\text { bers } \%\end{array}$
\end{tabular}

Health problems

Family commitments

Personal problems

Feeling too tired

Pain associated with exercise

Laziness

Lack of exercise facilities

Feeling unsafe

Fear of losing weight

Financial problems

Feeling insecure

Not interested

Forgetfulness

Transport and

distance problems

Feeling upset

Too old for gym

\begin{tabular}{rr}
23 & 7 \\
15 & 5 \\
15 & 0 \\
15 & 17 \\
12 & 13 \\
4 & 37 \\
0 & 30 \\
4 & 22 \\
0 & 2 \\
0 & 0 \\
0 & 3 \\
0 & 2 \\
0 & 2 \\
0 & 3 \\
0 & 2 \\
0 & 3 \\
\hline
\end{tabular}

Note: Participants may have more than 1 response. Totals may therefore exceed $100 \%$.

Perceived enhancing factors to improved physical activity by members were: own motivation and confidence, having sufficient time, the health benefits, feeling good after exercise and visiting the gym and having community support. Those perceived by non- members were: having sufficient time, having community support, own motivation and confidence and having an exercise partner. 
Table 4: Members and non-members perceived enhancing factors for physical activity

\begin{tabular}{lcc}
\hline $\begin{array}{l}\text { Perceived } \\
\text { enhancers }\end{array}$ & $\begin{array}{l}\text { Club } \\
\text { members } \%\end{array}$ & $\begin{array}{c}\text { Community } \\
\text { members } \%\end{array}$ \\
\hline $\begin{array}{l}\text { Own motivation } \\
\quad \text { and confidence }\end{array}$ & 31 & 25 \\
$\begin{array}{l}\text { Having suffic- } \\
\quad \text { ient time }\end{array}$ & 23 & 37 \\
Health benefits & 23 & 3 \\
Having community & 12 & 28 \\
$\quad$ support & 19 & 2 \\
$\begin{array}{l}\text { Feeling good after } \\
\quad \text { exercise /gym }\end{array}$ & & \\
Having an exercise & 4 & 13 \\
$\quad$ partner & & 0 \\
Interest/curiosity & 4 & 2 \\
Excitement & 4 & 2 \\
Being happy & 0 &
\end{tabular}

Note: Participants may have more than 1 response. Totals may therefore exceed $100 \%$.

\subsection{Dietary Habits}

3.2.1 Consumption of Fat Containing Foods: These included untrimmed fat and/or skin from red meat and chicken, frying of meat as a cooking method and the consumption of sour milk, margarine, fat cookies, offal and pork.

Sixty- nine percent of the members always trimmed fat whereas 79 percent of non- members never trimmed fat from red meat. The difference was statistically significant $(\mathrm{p}=0.000)$. Forty- six percent of members always trimmed fat and skin from chicken whereas 86 percent of non-members never did this. This difference was statistically significant $(\mathrm{p}=0.000)$. Although there was no statistical difference in the methods of cooking of meats, fewer members fried their meats in oil than members (data not shown).

The commonly used spread was margarine with 50 percent of members and 43.5 percent of non-members. Of those that ate margarine, 38.5 percent of members and 96 percent of non- members used soft margarine instead of hard margarine. This difference is statistically significant ( $\mathrm{p}$ $=0.000)$.

Fat cookies are white bread rolls fried in oil, similar to doughnuts. Approximately 60 percent of all respondents reported not eating fat cookies at all while 12 percent of members and 3 percent of non- members respectively reported that they ate fat cookies 3 or more times a week. Although not statistically significant, members ate more fat cakes than non-members (12\% of members and $3 \%$ of non-members respectively ate fat cookies 3 or more times a week).
3.2.2 Consumption of Food Rich in Protein: This included 'lentils, samp and beans', red meat, chicken, sausage, fish, eggs and milk. Participants were asked how many times per week they ate lentils, samp and beans; red meat; chicken and sausage.

A large percentage of respondents consumed lentils, samp (maize) and beans but members ate more of these products than non-members. The difference was statistically significant, $(p=0.009)$.

Fifty- eight percent and 19 percent of members and non-members respectively never ate red meat. There was a little difference between members and non-members in consumption of chicken. Although more members $(31 \%)$ did not eat any sausage as compared to non-members $(16 \%)$, this difference is not statistically significant.

Members and non-members' consumption of eggs was similar with no statistically significant difference. Twenty percent of members and 32 percent of non-members did not eat eggs at all. Twenty- eight percent of members and 14 percent of non-members ate 3 or more eggs per week.

3.2.3 Consumption of Sugar Containing Foods: This included teaspoons of sugar in tea/ coffee and sweetened beverages. Members consumed less sugar with 36 percent and 5 percent of members and non-members respectively using less than 2 teaspoons and 68 percent and 32 percent of non- members and members respectively using 3 or more teaspoons in their hot beverages. This difference is highly significant ( $\mathrm{p}=$ 0.000). Carbonated drinks (Coke, Fanta, Sprite, etc.) and sweetened juice were the preferred cold drinks by all participants in summer. Of the members, 62 percent drank 1 glass of their preferred beverage compared to non-members, of whom 66 percent drank 3 or more glasses daily in summer. This difference in consumption is highly significant $(\mathrm{p}=0.000)$.

3.2.4 Salt Intake: Members consumed less salt than non-members. None of the club members and 7percent of non-members preferred their food to be very salty. Of those who used salt, 68 percent of members and 81 percent of non-members added salt to their food while cooking.

3.2.5 Daily Consumption of Fruit and Vegetables: A portion of vegetables was described as a fist-sized amount of vegetables. Fruit consumption was similar for both groups with 56 percent of members and 63 percent of non-mem- 
bers having consumed 2-3 fruits daily. Vegetable consumption was also similar with 81 percent of members and 77 percent of non-members having consumed 2-3 portions daily.

3.2.6 Participants'Access to Refrigeration: This was regarded as a proxy to socio-economic position. Fewer members (62\%) than non-members $(83 \%)$ had access to refrigeration. This difference is significant $(\mathrm{p}=0.028)$.

3.2.7 Perceived Barriers and Enhancing Factors to Improving Dietary Habits of Participants: Participants were given a list of perceived barriers and perceived enhancers for improved dietary habits some of which were drawn from Chopra and Puoane (2003). They were asked to choose those that applied to them and to add any that were not on the list (see Tables 5 and 6).

Table 5: Members and non-members perceived barriers for improved dietary habits

\begin{tabular}{lcc}
\hline $\begin{array}{l}\text { Perceived } \\
\text { barriers }\end{array}$ & $\begin{array}{c}\text { Members } \\
\%\end{array}$ & $\begin{array}{c}\text { Non-members } \\
\%\end{array}$ \\
\hline Healthy food too expensive & 73 & 80 \\
$\begin{array}{l}\text { Healthy food not easy to } \\
\quad \text { find }\end{array}$ & 27 & 15 \\
Available food is too & 12 & 13 \\
$\quad$ tempting & 8 & 2 \\
$\quad$ Eating healthily makes me & & \\
$\quad$ isolated from others & 8 & 2 \\
Available food is nutritious & 4 & 0 \\
Health reasons & 0 & 5 \\
Fear of losing weight & 0 & 2 \\
Love meat & & \\
\hline
\end{tabular}

Note: Participants may have more than 1 response. Percentages may therefore exceed 100

The more common perceived barriers mentioned by both members and non-members were: healthy food was too expensive, healthy food was not easy to find and that available food was too tempting.

The common perceived enhancing factors mentioned by both members and non-members were: feeling healthier and confident, having more money, having family/ community curiosity and support and losing weight.

\section{DISCUSSION}

This study compared the health club members' physical activity and dietary habits with those of non-members to determine if members were
Table 6: Members and non-members perceived enhancing factors for improved dietary habits

\begin{tabular}{lcc}
\hline $\begin{array}{l}\text { Perceived } \\
\text { barriers }\end{array}$ & $\begin{array}{c}\text { Members } \\
\%\end{array}$ & $\begin{array}{c}\text { Non-members } \\
\%\end{array}$ \\
\hline $\begin{array}{l}\text { Feeling healthier } \\
\quad \text { and confident }\end{array}$ & 54 & 57 \\
$\begin{array}{l}\text { Having more } \\
\quad \text { money }\end{array}$ & 27 & 28 \\
$\begin{array}{l}\text { Family/community } \\
\quad \text { curiosity and }\end{array}$ & 8 & 8 \\
$\quad$ support & & \\
Losing weight & 4 & 12 \\
Eating healthily & 4 & 0 \\
Vitamins and irons & 4 & 0 \\
Be strong by yourself & 4 & 0 \\
Healthy food & 4 & 0 \\
$\quad$ is accessible & & \\
Personal hygiene & 4 & 0 \\
Food gardening & 0 & 5 \\
Better eyesight & 0 & 2 \\
Feeling strong & 0 & 2
\end{tabular}

Note: Participants may have more than 1 response. Percentages may therefore exceed $100 \%$.

making healthier lifestyle choices than non-members.

Two important issues regarding behaviour modification emerged from this study. Firstly, participation in the health club does provide members with the opportunity to enhance their lifestyle practices of physical activity and eating habits more than that of non-members. Health clubs, because of the social support it provides to its members, can serve as a vehicle to enhance behaviour modification. For example, club members mostly practiced healthier eating than nonmembers. They consumed more vegetable based legumes and maize porridge, less red meat and foods high in fat, used less sugar in hot beverages as well as less sweetened cool drinks. They also used healthier food preparation methods namely removing fat and skin from meat and chicken and often did not fry meat. It has been shown that group physical activity programmes do affect improvements in psychosocial outcomes for older adults (WHO 2009). Secondly, it was determined that even though the club members were given necessary information to assist them in making lifestyle changes, their socioeconomic position and the environment in which they reside had an influence in that, contrary to expectation, members consumed more hard (rather than soft margarine), the same amount of fat cakes, and less fish than non-members. This could be due to other factors that influence food choice. 
The FBDG recommend participation in physical activities of moderate intensity for at least 30 minutes on most days of the week or three times a day for as little as ten minutes at a time (Lambert et al. 2001a). Qualify their sentence: Suggestions would be paragraph under the heading 3.1 .2 on page 3 more members than non-members.

In this paper watching television was a proxy of physical inactivity. Although time spent watching television was common among all respondents, club members watched less television than non-members. It has been found that an inverse association exists between television watching and physical activity for both boys and girls (Crespo et al. 2008). However, to encourage less TV viewing may be challenging in the townships as the activity may provide a means of entertainment /leisure in an environment where there may be a lack of other social activities as well as a fear of going outside due to issues of crime.

The FBDG recommend that fats be used sparingly. Although this is a vague description, it does appear that club members are generally complying with this recommendation. This was an achievement on the part of health club members particularly as fatty and unhealthy foods are so readily available in the community. Chopra and Puoane (2003) assessed environmental influences on obesity in Khayelitsha. They reported that there was a shortage of healthy low fat food and little fruit and vegetables are available in the townships. They further noted that the majority of the local shops sell cheap, fatty foods and street vendors sell fatty meat and sausages. Similarly, Drewnowski and Popkin (1997) found that cheap vegetable fats and oils were easily accessible globally to poorer communities and had resulted in increased fat intakes and concomitant increasing risk of chronic non-communicable disease in developing countries.

Health club members also ate less red meat and fish; more lentils, samp and beans; and similar quantities of eggs and chicken as non-members. This does generally comply with the FBDG which recommends small portions of animal protein and encourages the eating of legumes. Reasons for eating less red meat and fish could be due to increasing health awareness (for the red meat) and/or financial constraints as red meat, especially healthy cuts with less fat, and fresh fish is expensive and therefore probably unaffordable.

It has been previously reported that consump- tion of fruit and vegetables increased with urbanization (Vorster et al. 1999). Both club members and non-members ate sufficient amounts of fruit and vegetables daily, which seem to comply with FBDG recommendations of 3-5 portions daily. However, it could be assumed that this would be achieved with some difficulty since data from local shops in the same area, reported that there are few stalls selling fruit and vegetables , the quality thereof appeared poor (Puoane et al. 2006). As regards barriers to improved physical activity and eating patterns, it has been suggested that programmes for older adults must reduce barriers by addressing accessibility (WHO 2009). They state examples of conducting physical activity programmes at venues where older adults meet regularly as well as home delivery of fresh fruit and vegetables (WHO 2009).

The literature shows that community-based efforts to reduce the risk of cardiovascular disease can influence behavior (Schooler et al. 1997). According to the Health Belief Model or HBM (Glanz 2002), this may be due to members having mentally assessed five key concepts. Each of these five concepts are either regarded as a threat (to improving behaviour) or as a measure of the 'pros'or 'cons' (of making changes). Members may have taken the preventive action of improving their lifestyle choices by measuring the outcomes of five concepts which are: (1) perceived seriousness (2) perceived susceptibility (3) perceived benefits (4) perceived barriers and (5) perceived cues to action (Sarafino 2006). Members who have instituted healthier changes may have perceived a threat large enough to overcome the perceived barriers. This would also have been prompted by the sum of their perceived benefits and enhancing factors according to the HBM.

Although this was not the focus of this research; apart from health benefits, participation in community organisations such as the health club could provide the opportunity to build on social supports, improve social networks, companionship and caring for the wellbeing of others. However, unexpected results and factors identified by participants suggest that, socioeconomic and environmental factors pose significant barriers to the adoption of healthy behaviours.

\section{ACKNOWLEDGEMENTS}

This study would not have been accomplished without the health club members as well as com- 
munity members. Thanks to the field workers who helped with the logistics of data collection and the National Research Foundation (NRF) for assistance towards funding for this research. Any opinion, findings and conclusions or recommendations expressed in this work are those of the authors and therefore the NRF does not accept any liability in regard thereto.

\section{REFERENCES}

Bourne LT, Lambert EV, Steyn K 2000. Where does the Black population of South Africa stand on the nutrition transition? Public Health Nutrition, 5(1A): 157-162.

Chopra M, Puoane T 2003. Prevention of diabetes throughout an obesogenic world. Diabetes Voice (Special Issue), 48: 24-26.

Crespo CJ, Smit E, Troiano RP, Bartlett SJ, Macera CA, Andersen RE March 2001. Television watching, energy intake, and obesity in US children: Results From the Third National Health and Nutrition Examination Survey, 1988-1994. Archives of Pediatric and Adolescent Medicine, 155: 160-165.

Drewnowski A, Popkin BM 1997. The nutrition transition: New trends in the global diet. Nutritional Review, 55 (2): 31-43.

Du Toit A, Neves D 2007. In Search of South Africa's Second Economy: Chronic Poverty, Vulnerability and Adverse Incorporation in Mount Frere and Khayelitsha. Prepared for the Living on the Margins Conference, Stellenbosch. From <http://www.chronic poverty.org/uploads/publication_files/WP102_ DuToit_Neves.pdf> (Retrieved October 6 2010).

Glanz K, Rimer BK, Lewis FM 2002. Health Behaviour and Health Education Theory, Research and Practice. San Francisco: Wiley and Sons.

Lambert EV, Bohlman K, Kolbe- Alexander T 2001a. Be active- Physical activity for health in South Africa. SAJCN, 14(3): S12- S16.

Lambert EV, Lambert MI, Hudson K, Steyn K, Levitt NS, Charlton KE, Noakes TD 2001b. The role of physical activity for health in communities undergoing epidemiological transition. World Review of Nutrition and Dietetics, 90: 110-126.

Lambert EV, Alexander K 2006. Chapter 3: Physical activity and chronic diseases of lifestyle in South Africa. Chronic Diseases of Lifestyle in South Africa: 1995-2005. Medical Research Council- Technical Report, pp. 23-32.

Levitt NS, Steyn K, Lambert EV, Reagon R, Lombard CJ, Fourie JM et al. 1999. Modifiable risk factors for Type 2 diabetes in a peri-urban community in South Africa . Diabet Med, 16: 946-950.

Peberdy S 2009. Setting the Scene: Migration and Urbanisation in South Africa. From <www.gcro.ac.za/ sites/default/files/News.../3_Setting_the_scene $>$. (Retrieved December 20, 2010).

Puoane T, Bradley H 2006. Primary prevention of noncommunicable diseases by community health workers: A case study of health and development. AFRICANUS Jnl of Developmental Studies, 33(2): 29-34.

Sarafino EP 2006. Health Psychology: Bio-psychosocial Interactions. 5th Edition. New York: Wiley and Sons Inc.

Schooler C, Farquhar JW, Fortmann SP, Flora, JA 1997. Synthesis of findings and issues from community prevention trials. Annals of Epidemiology, 7(7): 5468.

Steyn N 2006. Chapter 4. Nutrition and chronic diseases of lifestyle in South Africa. Chronic Diseases of Lifestyle in South Africa 1995-2005. Medical Research Council Technical Report.

Vorster HH, Bourne LT, Venter CS, Oosthuizen W 1999. Contribution of nutrition to the health transition in developing countries. Nutrition Reviews, 57(11): 341349.

Vorster HH, Love P, Bourne C 2001. Development of the food-based Dietary guidelines for South Africa - The Process. SAJCN, 14(3): S3-S6 (Supplement).

WHO 1997. World Health Report. Conquering Suffering, Enriching Humanity. Geneva: WHO

WHO 2004. Global Strategy on Diet, Physical Activity and Health. 57th World Health Assembly. Agenda Item 12.6. Geneva: WHO.

WHO 2009. Interventions on Diet and Physical Activity: What Works: Summary Report. Geneva: WHO.

Wikipedia online dictionary. Khayelitsha. From <http:// en.wikipedia.org./wiki/Khayelitsha>. (Retrieved December 13, 2010).

Yach D, Hawkes C, Linn Gould C, Hofman KJ 2004. The global burden of chronic diseases: Overcoming impediments to prevention and control. JAMA, 291: 2616-2622. 